\title{
Antiproliferative Effects of Carvacrol on Neuroblastoma Cells
}

Gizem Calibasi Kocal $\odot$ Ahu Pakdemirli $\odot$

\author{
Karvakrolün Nöroblastom Hücreleri Üzerindeki \\ Antiproliferatif Etkisi
}

\begin{abstract}
Objective: Neuroblastoma is a pediatric solid tumor that originates from the neural crest. The survival rate of these malignancies is below $50 \%$. The most common treatments for the disease have several adverse effects which make them invasive for patients and limits the applicability as well as continuity of the treatment. Therefore, researchers seek new agents to reduce adverse effects in order to improve the treatment. In this wise, plant-derived phytochemicals are promising drug candidates, such as carvacrol which has anti-cancer features in some cancers.

Method: Human neuroblastoma cell lines, KELLY (N-MYC positive) and SH-SY5Y (N-MYC negative) were grown in RPMI 1640 (KELLY) or DMEM (SH-SY5Y). Cells were treated with a range of concentration of carvacrol. Cellular proliferation was monitored by using xCELLigence Real-Time Cell Analyzer (RTCA) (ACEA Biosciences, Inc.) device to evaluate the antiproliferative effect of carvacrol on the neuroblastoma cells. Results: Considering the proliferation curve of SH-SY5Y, results indicate that carvacrol has antiproliferative effects on N-MYC negative neuroblastoma cells, SH-SY5Y cells at all concentrations.

Conclusion: The data illuminate that the carvacrol has an antiproliferative role on neuroblastoma cells. In this context, this phyto-compound might be a promising agent for the treatment of this malignancy.
\end{abstract}

Keywords: Carvacrol, neuroblastoma, proliferation, pediatric cancers

Öz

Amaç: Nöroblastom, nöral krest kaynaklı pediyatrik bir solid tümördür. Bu malignitelerin hayatta kalma oranı \%50'nin altındadır. Hastalık için en yaygın tedavilerin, hastalar için invaziv olmasını sağlayan ve tedavinin uygulanabilirliğini ve sürekliliğini sınırlayan çeșitli olumsuz etkileri vardır. Bu nedenle, araştırmacılar tedaviyi iyileştirmek ve olumsuz etkileri azaltmak için yeni ajanlar aramaktalar. Bu açıdan bitki kaynaklı fitokimyasallar, bazı kanserlerde anti-kanser özelliklerine sahip olan karvakrol gibi umut verici ilaç adaylaridır.

Yöntem: Insan nöroblastom hücre dizileri, KELLY (N-MYC pozitif) ve SH-SY5Y (N-MYC negatif) RPMI 1640 (KELLY) veya DMEM'de (SH-SY5Y) büyütüldü. Hücreler bir dizi karvakrol konsantrasyonu ile muamele edildi. Hücresel proliferasyon, karvakrolün nöroblastom hücreleri üzerindeki anti-proliferatif etkisini değerlendirmek için xCELLigence Gerçek Zamanlı Hücre Analiz Cihazı (RTCA) (ACEA Biosciences, Inc.) cihazı kullanıldı. Bulgular: SH-SY5Y'nin proliferasyon eğrisi göz önüne alındığında, sonuçlar karvakrolün tüm konsantrasyonlarda N-MYC negatif nöroblastom hücreleri SH-SY5Y hücreleri üzerinde anti-proliferatif etkilere sahip olduğunu göstermektedir.

Sonuç: Veriler, karvakrolün nöroblastom hücreleri üzerinde anti-proliferatif bir role sahip olduğunu aydınlatmaktadır. Bu bağlamda, bu fitokimyasal malignite için umut verici bir ajan olabilir.

Anahtar kelimeler: Karvakrol, nöroblastoma, proliferasyon, çocukluk çağı kanserleri
Alındığı tarih: 31.01 .2020

Kabul tarihi: 06.02.2020

Online Yayın tarihi: 30.03 .2020

Ahu Pakdemirli University of Health Sciences Gulhane School of Medicine,

Department of Physiology,

Ankara, Turkey

ahu@pakdemirli.com

ORCiD: 0000-0001-9224-3007

G. Calibasi Kocal 0000-0002-3201-4752 Dokuz Eylul University, Institute of Oncology, Department of Translational Oncology, Izmir, Turkey 


\section{INTRODUCTION}

Data acquired since 1975 indicate an increase in cases, especially in developed countries (4,5). Childhood cancers take the second place after child accidents in developed countries, although they are rare diseases when all cancer cases are evaluated (1,2). According to the September 2018 data of the World Health Organization, 300.000 children are diagnosed with cancer every year from birth to the

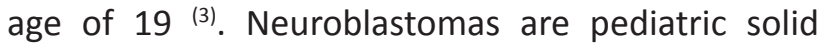
tumors originating from neural crest, which are mostly seen in children aged $0-5$ years. The survival rate of these malignancies is below $40 \%$ and differs in subtypes ${ }^{(6)}$. This disease is rarely hereditary and only $1 \%$ of all cases have familial origin. Treatment strategies of neuroblastoma generally depend on risk groups of disease. Generally older children with metastatic tumors with extra MYCN copies are accepted as high stage tumors; and infants with even metastatic tumors without MYCN copies are considered as low risk. Chemotherapy of neuroblastoma generally includes combination of chemotherapeutic agents such as cyclophosphamide, cisplatin, carboplatin, vincristine, doxorubicin (Adriamycin), etoposide, topotecan, and busulfan ${ }^{(7,8)}$. While all of these treatment strategies have their own adverse effects, the adverse effects related to systemic chemotherapy is much restrictive due to their higher mortality rates.

Several studies indicate some phytochemicals have promising favorable effects on diseases with lower adverse effects as an alternative way to these therapies ${ }^{(9)}$. Phytochemicals are plant-derived secondary metabolites having organic contents as alkaloids, terpenes, and phenolic compounds. A submember of the terpene family, monoterpenes, are biologically active substances present in aromatic plants like thyme, pepperwort and wild bergamot. Researchers have revealed that these compounds like menthol, geraniol, linalool have anti-oxidant, anti-obesity, anti-cancer, as well as many more biological activities ${ }^{(10,11)}$. Likewise, another phenolic monoterpene, carvacrol is found in oregano and thymus derived essential oils. It is a good candidate due to its several anti-cancer effects (Figure 1) ${ }^{(12,13)}$. Therefore, this study was designed to understand the effect of carvacrol on neuroblastoma cell lines, KELLY and SH-SY5Y (14).

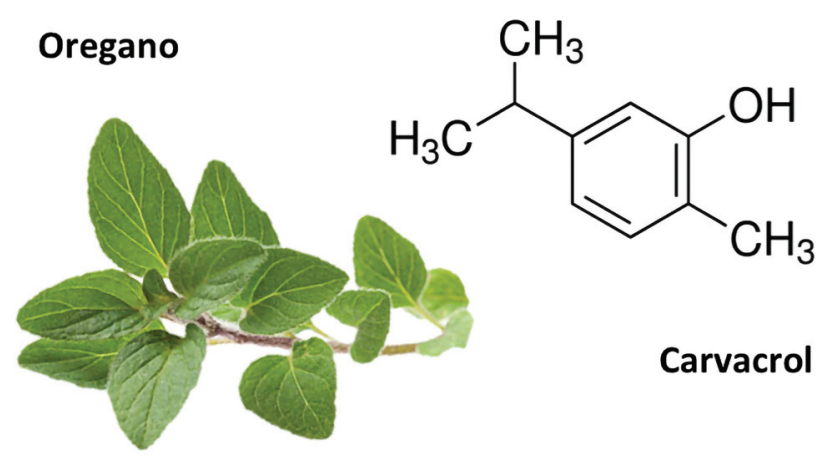

Figure 1. Structure of carvacrol as a phenolic monoterpene.

\section{MATERIAL and METHODS}

\section{Cell Culture}

Human neuroblastoma cell lines, KELLY (N-MYC positive) and SH-SY5Y (N-MYC negative) were grown in RPMI 1640 (KELLY) or DMEM (SH-SY5Y) supplemented with $10 \%$ fetal bovine serum, $1 \%(\mathrm{v} / \mathrm{v})$ penicillin/streptomycin and $1 \% \mathrm{~L}$-glutamine in a $5 \% \mathrm{CO}_{2}$ incubator at $37^{\circ} \mathrm{C}$.

\section{Real-Time Cell Proliferation Assay}

The principle of xCELLigence Real-Time Cell Analyzer (RTCA) Single-Plate (SP) system (ACEA Biosciences, Inc.) is to reveal the impedance changes by the interaction of adherent cells to the gold microelectrodes. Cells ( $10^{4}$ cells/well) cultured in 96-well plate for 24 hours. Test compounds were added to the growth medium after 24 hours of seeding and scanned for 48 hours to see the effect of chemotherapeutics.

\section{RESULTS}

The effects of carvacrol on the proliferation of neuroblastoma cancer cell line KELLY and SHSY5Y, were investigated by real time cell analysis system. Three different doses, as $12.5 \mu \mathrm{M}, 25 \mu \mathrm{M}$ and 50 $\mu \mathrm{M}$, were applied to see the effects of carvacrol on KELLY and SH-SY5Y. According to the results, carvac- 
rol showed antiproliferative effects on both KELLY and $\mathrm{SH}-\mathrm{SY} 5 Y$ cell. On SH-SY5Y cells, antiproliferative effect of carvacrol was seen on $25 \mu \mathrm{M}$ and $50 \mu \mathrm{M}$ doses. The application of $12.5 \mu \mathrm{M}$ dose carvacrol, did not show an anti-proliferative or proliferative effect (Figure 2). All carvacrol doses (12.5 $\mu \mathrm{M}, 25 \mu \mathrm{M}$ and $50 \mu \mathrm{M}$ ) applied on KELLY cells showed antiproliferative effect (Figure 3 ).

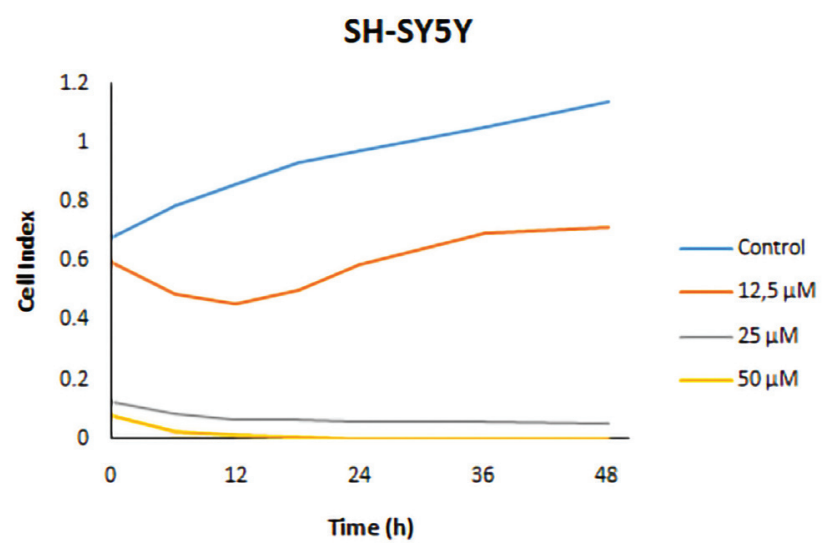

Figure 2. Anti-proliferative effect of carvacrol on SH-SY5Y cell line.

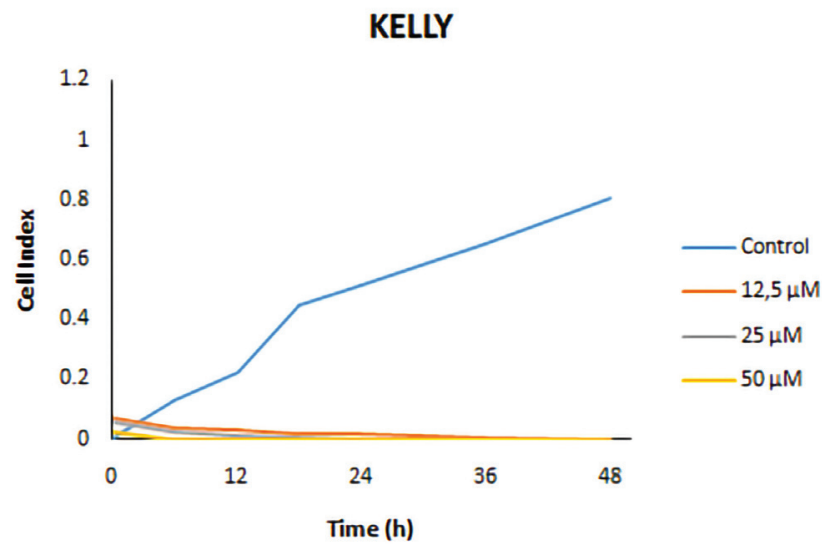

Figure 3. Anti-proliferative effect of carvacrol on KELLY cell line.

\section{DISCUSSION}

Plant-derived compounds attract many researchers for their desire to discover new therapeutic approaches in order to reach more applicable and sustainable therapies, in parallel with their day by day increasing interest in use of phytochemicals also in cancer research. This study illuminates the role of a phenolic compound named carvacrol on a well- known pediatric malignancy, neuroblastoma for its antiproliferative properties. Several researches illuminate antiproliferative role along with some other anti-cancer features of carvacrol on some adulthood cancers in the past. This phyto-compound envokes apoptosis and cell cycle arrest in human prostate, liver, lung, colorectal and cervial cancers ${ }^{(1-5)}$. This study has focused on the antiproliferative effect of this substance on human neuroblastoma cell lines KELLY and SH-SY5Y. The data of this study illuminate that the carvacrol has antiproliferative effect on both KELLY and SH-SY5Y cell lines. The application of 25 $\mu \mathrm{M}$ or $50 \mu \mathrm{M}$ carvacrol, shows antiproliferative effect on both KELLY and SH-SY5Y cells. But $12.5 \mu \mathrm{M}$ dose of carvacrol shows different results according to the cell type. Lower doses of carvacrol may have different effects on different neuroblastoma cells. In summary, this study has suggested that a plantbased phyto-compound, carvacrol can be used to inhibit proliferative feature of neuroblastoma cells, KELLY and SH-SY5Y.

Conflict of Interest: The authors of the study have no conflict of interest.

Funding: There is no funding in this study.

Informed Consent: This study doesn't include human trials and informed consent is not required.

\section{REFERENCES}

1. Stiller CA. Epidemiology and genetics of childhood cancer. Oncogene. 2004;23(38):6429-44. https://doi.org/10.1038/sj.onc.1207717

2. Kaatsch P. Epidemiology of Childhood Cancer. Cancer Treat Rev 2010;36(4):277-85. https://doi.org/10.1016/j.ctrv.2010.02.003

3. WHO. "Cancer in Children." Who.Int, World Health Organization: WHO, 28 Sept. 2018, www.who.int/newsroom/fact-sheets/detail/cancer-in-children. Accessed 25 Mar. 2020

4. Noone A, Howlader N, Krapcho M, et al. SEER Cancer Statistics Review, 1975-2015. National Cancer Institute. Bethesda, MD.

5. Steliarova-Foucher E, Fidler MM, Colombet $\mathrm{M}$, et al. Changing geographical patterns and trends in cancer incidence in children and adolescents in Europe, 1991-2010 (Automated Childhood Cancer Information System): a population-based study. Lancet Oncol. 2018;19(9):1159-69. https://doi.org/10.1016/S1470-2045(18)30423-6

6. Pfeil J, Thornton A, Durbin A, et al. Gene expression analysis for improved subtyping of high-risk neuroblastoma. J Clin 
Oncol. 2018; 36, no.15 (May 20, 2018) 10559-10559. https://doi.org/10.1200/jco.2018.36.15_suppl.10559.

7. Esposito MR, Aveic S, Seydel A, Tonini GP. Neuroblastoma treatment in the post-genomic era. J Biomed Sci. 2017;24(1):14. https://doi.org/10.1186/s12929-017-0319-y

8. Smith V, Foster J. High-Risk Neuroblastoma Treatment Review. Children. 2018;5(9):114. https://doi.org/10.3390/children5090114

9. Greenlee H. Natural Products for Cancer Prevention. Semin Oncol Nurs. 2012; 28(1):29-44. https://doi.org/10.1016/j.soncn.2011.11.004

10. Kotecha R, Takami A, Espinoza JL. Dietary phytochemicals and cancer chemoprevention: A review of the clinical evidence. Oncotarget. 2016;7(32):52517-29. https://doi.org/10.18632/oncotarget.9593

11. Arumai Selvan D, Mahendiran D, Senthil Kumar R, Kalilur Rahiman A. Garlic, green tea and turmeric extracts-mediated green synthesis of silver nanoparticles: Phytochemical, antioxidant and in vitro cytotoxicity studies. J Photochem Photobiol B Biol. 2018. https://doi.org/10.1016/j.jphotobiol.2018.02.014

12. Mirzaei H, Masoudifar A, Sahebkar A, et al. MicroRNA: A novel target of curcumin in cancer therapy. J Cell Physiol. 2017;180:243-52. https://doi.org/10.1002/jcp.26055

13. Luo Y, Wu JY, Lu MH, Shi Z, Na N, Di JM. Carvacrol Alleviates Prostate Cancer Cell Proliferation, Migration, and Invasion through Regulation of PI3K/Akt and MAPK Signaling Pathways. Oxid Med Cell Longev. 2016;2016:1469693 https://doi.org/10.1155/2016/1469693

14. Fan K, Li X, Cao Y, et al. Carvacrol inhibits proliferation and induces apoptosis in human colon cancer cells. Anticancer Drugs. 2015;26(8):813-23. https://doi.org/10.1097/CAD.0000000000000263
15. Yin $Q H$, Yan FX, Zu XY, et al. Anti-proliferative and proapoptotic effect of carvacrol on human hepatocellular carcinoma cell line HepG-2. Cytotechnology. 2012;64(1):43-51. https://doi.org/10.1007/s10616-011-9389-y

16. Jung $C Y$, Kim SY, Lee $C$. Carvacrol targets $A X L$ to inhibit cell proliferation and migration in non-small cell lung cancer cells. Anticancer Res. 2018;38(1):279-86.

https://doi.org/10.21873/anticanres.12219

17. Khan F, Singh VK, Saeed M, Kausar MA, Ansari IA. Carvacrol Induced Program Cell Death and Cell Cycle Arrest in Androgen-Independent Human Prostate Cancer Cells via Inhibition of Notch Signaling. Anticancer Agents Med Chem. 2019;19(13):1588-608. https://doi.org/10.2174/1871520619666190731152942

18. Fan K, Li X, Cao Y, et al. Carvacrol inhibits proliferation and induces apoptosis in human colon cancer cells. Anticancer Drugs. 2015;26(8):813-23. https://doi.org/10.1097/CAD.0000000000000263

19. Potočnjak I, Gobin I, Domitrović R. Carvacrol induces cytotoxicity in human cervical cancer cells but causes cisplatin resistance: Involvement of MEK-ERK activation. Phytother Res. 2018;32(6):1090-7. https://doi.org/10.1002/ptr.6048

20. Luo Y, Wu JY, Lu MH, Shi Z, Na N, Di JM. Carvacrol Alleviates Prostate Cancer Cell Proliferation, Migration, and Invasion through Regulation of PI3K/Akt and MAPK Signaling Pathways. Oxid Med Cell Longev. 2016;2016:1469693. https://doi.org/10.1155/2016/1469693

21. Khan I, Bahuguna A, Bhardwaj M, Pal Khaket T, Kang SC. Carvacrol nanoemulsion evokes cell cycle arrest, apoptosis induction and autophagy inhibition in doxorubicin resistantA549 cell line. Artif Cells Nanomed Biotechnol. 2018;46(sup1):664-75. https://doi.org/10.1080/21691401.2018.1434187 